\title{
Residual volume in vials of antibiotics used in pediatrics
}

\author{
Volume residual de antibióticos em frascos-ampola utilizados na pediatria \\ Volumen residual de antibióticos en frascos-ampolla utilizados en pediatría
}

Caroline Magna Pessoa Chaves', Carolina Martins Bezerra', Francisca Elisângela Teixeira Lima ${ }^{1}$ Maria Vera Lúcia Moreira Leitão Cardoso ${ }^{1}$, Said Gonçalves da Cruz Fonseca², Viviane Martins da Silva ${ }^{1}$

How to cite this article:

Chaves CMP, Bezerra CM, Lima FET, Cardoso MVLML, Fonseca SGC, Silva VM. Residual volume in vials of antibiotics used in pediatrics. Rev Esc Enferm USP. 2017;51:e03234. DOI: http://dx.doi.org/10.1590/S1980-220X2016046603234

${ }^{1}$ Universidade Federal do Ceará, Departamento de Enfermagem, Programa de Pós-Graduação em Enfermagem, Fortaleza, CE, Brazil.

${ }^{2}$ Universidade Federal do Ceará, Departamento de Farmácia, Fortaleza, CE, Brazil.

\begin{abstract}
Objective: Quantifying residual volume contained in vials of antibiotics used in pediatrics. Method: This is an experiment involving samples from vials of antibiotics used in a pediatric hospital. Residual volume was identified by calculating the difference in weight measurement before and after the vials were washed. Evaluation of the residual volume difference in the vials was determined by the Wilcoxon non-parametric test for a sample and established at a significance level of 5\%. Results: 105 samples of antibiotics were selected. The correct use of the antibiotics oxacillin $(88.57 \%)$ and ceftriaxone (94.28\%) predominated with low residual values. The same did not occur for procaine benzylpenicillin + potassium benzylpenicillin, since a greater residual volume was discarded in $74.28 \%$ of the vials. Conclusion: We highlight the need for improvements in managing antibiotics in the institution under study, so that the excess volume of the antibiotics in the vials is used within the acceptable stable time. It is also necessary that the disposal of the residual volume be adequately disposed, since it presents a risk to public health and the environment.
\end{abstract}

\section{DESCRIPTORS}

Residual Volume; Anti-Bacterial Agents; Infusions, Parenteral; Pediatric Nursing. 


\section{INTRODUCTION}

Among the drug classes, parenteral antibiotics are frequently used in pediatrics ${ }^{(1)}$. However, most drugs in the pharmaceutical market are not suitable for the pediatric age group, which often leads to the reuse of parenteral drugs in vials ${ }^{(2)}$. This occurs because in the vast majority of cases, the dose the child needs is lower than the commercial quantity ${ }^{(3)}$, so that there is residual volume remaining in the vials.

Furthermore, the practice of drug reconstitution ${ }^{(2)}$ is often required as a consequence of the lack of pediatric formulations, where part of a solid form is added with sterile water for injectable or physiological solutions to result in a liquid form. Dilution is also common, where the concentrated liquid form added to the sterile water for injections or to physiological solution results in a more diluted liquid form ${ }^{(4)}$.

Reusing medication in vials, commercial quantity medication dose, and the intended dose in the therapeutic regimen are of crucial importance in determining the residual volume ${ }^{(5)}$, which is the volume that remains in the vial after drug reconstitution, dilution and administration.

Upon perceiving that there is a residual volume of the drug after its reconstitution and administration in the case of vials with multiple doses, it is necessary to take into account the correct use of the maximum possible amount of the antibiotics, respecting the stability time after reconstitution and dilution ${ }^{(2)}$.

Moreover, the presence of residue in the packages, in addition to increasing hospital costs ${ }^{(5)}$ also implies the need for correct disposal, otherwise the residues pose a risk to public health and to the environment ${ }^{(6)}$.

In view of the above, the following question was raised: During the preparation of parenteral antibiotics used in pediatrics, is there excess medication remaining in the vials?

This study is relevant as it investigates the correct use of antibiotics in vials, which is influenced by appropriate conservation, dilution and administration ${ }^{(7)}$.

Questions within the context of patient safety are a matter of prominence and worldwide relevance, and aim to prevent harm due to inadequate techniques. Moreover, a broader perspective focused on health promotion provides empowerment and autonomy to professionals.

The purpose of this study was to quantify the residual volume contained in vials of antibiotics used in pediatrics.

\section{METHOD}

An experimental cross-sectional study conducted at the pharmacotechnical laboratory of the Universidade Federal do Ceará, in January 2016.

Vials of antibiotics after reconstruction and administration (of the content) to children of a hospital in Fortaleza, Ceará state which were destined to disposal were collected in order to obtain the data. This was conducted with authorization from the health institution and after authorization from the Research Ethics Committee of the Universidade Federal do Ceará, with protocol approval number 954.076. The study institution was chosen for being a specialized and municipal reference in pediatric care.
This institution has a standardized protocol for the reconstitution of injectable antibiotics which is performed by the nursing team. Regarding the drugs selected for the study, and according to hospital standardization, reconstitution was performed as follows: $5 \mathrm{~mL}$ of distilled water for $500 \mathrm{mg}$ oxacillin, $2 \mathrm{~mL}$ of distilled water for procaine benzylpenicillin $(300,000 \mathrm{IU})$ + potassium benzylpenicillin $(100,000 \mathrm{IU})$, and $10 \mathrm{~mL}$ of distilled water for $1 \mathrm{~g}$ of intravenous ceftriaxone.

Inclusion criteria for selecting each vial assigned for disposal were: having been reconstituted according to the hospital standardization; it contained identification with the date and time of preparation and dilution; it was at most 48 hours before the residual volume analysis; and it had no signs of residue degradation, such as color change or precipitate formation. A total of 186 vials of antibiotics were collected; however, analysis of the residual volume was carried out using 105 vials, since the others did not have the date and time identification of the dilution, or showed signs of residue degradation and/or precipitation. It is worth mentioning that the vials under study came from different laboratories.

In order to quantify the residue contained in the vials of the antibiotics after reconstitution, recommendations for the method of checking the excess volume recommended for injectable liquids contained in the Brazilian Pharmacopoeia were adapted, and all the necessary steps were performed, namely: 1 - Removing metal seals; 2 - Removing labels that could be damaged during the test; 3 - Individual weighing of each vial with its respective cap using an analytical balance (with precision of $0.1 \mathrm{mg}$ ); 4 - Removing vial contents; 5 Washing vials and caps with $6 \%$ hydrogen peroxide solution, running water and distilled water; 6 - Drying in oven at $105^{\circ} \mathrm{C}$ for at least one hour, or at a temperature compatible with the vial material; 7 - Cooling at room temperature; 8 - Placing vial caps back on; 9 - Performing a new weighing of the vials and cap together ${ }^{(4)}$.

The form used in this study was developed by the researchers and it included the following data: name of the antibiotic, presentation/appearance, date of preparation and dilution, weight values before and after removing the vial contents, records of the weight difference for determining the residual volume of each vial.

All the steps of the study were followed by the pharmaceutical researcher responsible for the laboratory, and the experiments were carried out by two researchers. Firstly, at the end of the morning shift the researchers collected the vials destined to be discarded at the hospital, obeying the stability time of each one. The vials were then taken to the laboratory and the steps for measuring the residual volume were initiated. The samples were collected at the hospital for eight days in order to obtain a larger number of samples and for the convenience of the analyzers.

The pharmacotechnics laboratory only has one entrance with a height of 4 meters, lighting with fluorescent lamps without the incidence of direct sunlight, and temperature maintained by a split air conditioner regulated to $22^{\circ} \mathrm{C}$ with relative humidity around $50 \%$. The drugs were separated by antibiotic class and the labels were removed. Next, vials 
and caps were numbered and weighed using an accuratelycalibrated and precision-tested PRECISA 205 ASCS ${ }^{\circledR}$ analytical balance, which was turned on 30 minutes before the start of the analyzes.

After weighing the containers with the drug residue, vials and caps were separated and sequentially washed with $6 \%$ hydrogen peroxide solution, running water and distilled water. The residues were removed using a wash bottle to shoot distilled water directly into the entire interior of the vial, and to wash the inside of the lid. The residue obtained from the wash was collected, treated with hydrogen peroxide and then discarded.

At the end of this process, the vials were inspected to identify any fragment of adhered antibiotic that might not have been removed with the washing steps described above; in this case, the washing would be repeated until fragments were completely removed. The material was dried in an oven at $105^{\circ} \mathrm{C}$ for about six hours (to avoid the presence of liquid or moisture in the flask) and weighed again using the same analytical balance. The difference between the initial weight and the final weight represents the residue weight contained in each vial.

The results of the residual volumes of each vial were tabulated in Excel spreadsheets (Windows, 2010) and analyzed by software $R$, version 3.2.2. Data analysis was based on descriptive statistics with measures of central tendency and dispersion such as mean, median and standard deviation. Evaluation of the difference in residual volumes in the vials was determined by the Wilcoxon non-parametric test for a sample, establishing a level of significance of $5 \%$.

\section{RESULTS}

The therapeutic classes of the 105 antibiotics selected for the study were as follows: Penicillins represented by oxacillin (500 mg), procaine benzylpenicillin (300,000 IU) + potassium benzylpenicillin (100,000 IU), and third generation cephalosporin represented by ceftriaxone $(1 \mathrm{~g})$, with 35 samples of each.

The choice for the antibiotics analyzed in the study was determined by the fact that they were standardized in the hospital and due to their frequent use in the pediatric population. The manufacturer of each vial was not identified, as the focus of our study was to demonstrate the quantification of residue leftover after reconstitution of the antibiotic, and the importance of using it as much as possible, regardless of the drugs being manufactured by different laboratories.

We found that the amount of the oxacillin and ceftriaxone antibiotics analyzed in the vials presented lower residual values than those obtained from most procaine benzylpenicillin + potassium benzylpenicillin vials (Table 1 ).

Residual volume values ${ }^{(4)}$ shown in Table 1 are the same as in Table 2, and were used as limits due to the lack of specific reference regarding the amount of medicine that may remain in the vial after reconstitution and administration steps.

Table 2 shows the median weight in grams before and after washing, and mean residual weight of each antibiotic. Note that oxacillin and ceftriaxone antibiotics presented lower residual volumes than those observed for the procaine benzylpenicillin + potassium benzylpenicillin antibiotic.

Table 1 - Number of analyzed vials (N) according to the residual volume limit for each type of antibiotic - Fortaleza, Ceará, Brazil, 2016

\begin{tabular}{lcc}
\hline Residual Volume $(\mathrm{mL})$ & $\mathrm{N}$ & $\%$ \\
\hline Oxacillin & 31 & 88.57 \\
$\leq 0.3$ & 4 & 11.42 \\
$>0.3$ & & 25.71 \\
\hline Procaine benzylpenicillin + potassium benzylpenicillin & 9 & 74.28 \\
$\leq 0.15$ & 26 & \\
$>0.15$ & & 33 \\
\hline Ceftriaxone & 2 & 5.28 \\
$\leq 0.5$ & & 5.71 \\
\hline 0.5 & & \\
\hline
\end{tabular}

Source: Research Data (2016).

Table 2 - Measures of central tendency of the weights (in grams) before and after washing, residual volume (mL) of antibiotics in vials and recommended volume (mL) - Fortaleza, Ceará, Brazil, 2016.

\begin{tabular}{ccccc}
\hline Antibiotic & $\begin{array}{c}\text { Median and standard } \\
\text { deviation } \\
\text { Weight before }(\mathrm{g})\end{array}$ & $\begin{array}{c}\text { Median and standard } \\
\text { deviation } \\
\text { Weight after }(\mathrm{g})\end{array}$ & $\begin{array}{c}\text { Median and standard } \\
\text { deviation } \\
\text { Residual Volume }(\mathrm{g})\end{array}$ & $\begin{array}{c}\text { Minimal recommended } \\
\text { excess volume }\end{array}$ \\
\hline Oxacillin $(\mathrm{g})$
\end{tabular}

Source: Research data (2016). Brazilian Pharmacopeia ${ }^{(4)}$. 
A statistically significant difference was found from the results obtained in the Wilcoxon test for the three groups of analyzed antibiotics, with $\mathrm{p}=2.257 \times 10^{-9}$ for oxacillin, $\mathrm{p}=5.452 \times 10^{-5}$ for procaine benzylpenicillin + potassium benzylpenicillin, and $\mathrm{p}=1.879 \times 10^{-5}$ for ceftriaxone.

Despite not being the objective of the study, it was also observed that the nursing team discarded the vials of diluted antibiotics after the end of the shift before its acceptable stability time, without using all.

These residues were discarded without performing measures to inactivate leftover antibiotics in vials; this being divergent practice from legal provisions, raising a worrying concern for our clinical practice on how and where this waste is being disposed.

\section{DISCUSSION}

The types of analyzed antibiotics are in line with the profile of the most commonly used antimicrobials in a pediatric unit described in the scientific literature, such as ceftriaxone, cephalexin, gentamicin, ampicillin, oxacillin and procaine penicillin $G^{(7)}$.

Although the present study did not evaluate the preparation and administration of the antibiotics by the nursing team, the residual volume findings in the vials of oxacillin and ceftriaxone antibiotics represent the correct use and dilution of these drugs. In view of the complexity of parenteral administration, this is a positive factor due to the significant error rate related to this route ${ }^{(8-9)}$.

However, the fragility of the medication system is perceived as evidenced by the frequent doubts of the nursing team regarding drug preparation and administration $^{(10)}$. Thus, we highlight the need for professionals to have knowledge and access to drug information centers of the local universities, such as the Medicine Information Center of the Pharmacy Department of the Universidade Federal do Ceará.

Higher residual weight averages in the vials of the antibiotic procaine benzylpenicillin + potassium benzylpenicillin may have been influenced by the recommended dosage including longer time intervals, which makes it more difficult to reuse them, unlike the other antibiotics analyzed in the present study. The dosage for children is reduced and quite variable compared to that of an adult, leading to greater leftover antibiotics and thus a consequent increase in its waste.

These results reinforce the importance of using the volume contained in the vials to its maximum after reconstitution; in other words, the residual content in the vial should be used if within the acceptable stability time and maintained at the appropriate temperature until its full usefulness, regardless of the change in shifts of nursing professionals.

An observational study that analyzed aspects related to reconstitution, storage, temperature and labeling of medicines in vials in a pediatric unit found that from a total of 44 vials, only three contained all identifying items recorded on the label, posing a risk to the safety of its reuse ${ }^{(2)}$.
The residual volume results found still raise concerns about antibiotic management in the institution under study. It is worth mentioning that drug management programs have been implemented throughout many European hospitals, but nurse involvement has been limited even though it is described as being multidisciplinary in approach, which is due to the workload and high turnover of nursing staff ${ }^{(11)}$.

Medication management depends on correct medical prescription, dispensing, preparation and administration aimed at the rational use of medicine. Losses should be continuously avoided under penalty of being harmful to collective health and also to public funds ${ }^{(12)}$.

As the most consistent bedside care providers, nurses have an ideal position to improve antibiotic management through multidisciplinary collaboration, optimizing treatment, monitoring and administration, while improving pediatric patient safety and quality of care ${ }^{(11)}$.

The lack of parenteral drugs in adequate presentation for pediatrics represents a worldwide problem, constituting one of the factors that most contributes to the reuse of these medicines and also to increased care costs ${ }^{(13-14)}$.

The waste of antibiotics evidenced by the existence of residual volume reinforces another worrying finding, which is the inadequate disposal of the vials containing residual volumes of medicines. Such disposal represents a potential risk of contributing to antimicrobial resistance ${ }^{(15)}$, which is a threat to patient safety around the world ${ }^{(16)}$. Nurses also play an important role in the management of waste disposal, which may pose a risk to public health and to the environment ${ }^{(17)}$.

Waste disposal in the hospital area is framed in the technical regulation described by Resolution 306/2004 of the National Agency of Sanitary Surveillance on waste management of public and private health services, as well as by Resolution 358/2005 of CONAMA (Conselho Nacional do Meio Ambiente), which deals with the treatment and disposal of waste from health services ${ }^{(17-18)}$.

\section{CONCLUSION}

Oxacillin and ceftriaxone antibiotics presented residual volumes represented by the correct use and dilution of these drugs by the nursing team. In contrast, a higher residual volume was found in the vials of procaine benzylpenicillin + potassium benzylpenicillin antibiotics.

The residual volume results are worrisome due to inadequate disposal of the vials containing residual medicine volumes; this represents a potential risk of contributing to antimicrobial resistance, as well as the need for improving the management of antibiotics in the institution under study.

Although the study presents limitations as it was carried out in only one pediatric health institution, the scientific findings presented contribute to nurses for providing safe and quality care to children using medication treatment.

We also emphasize the importance of discussing antibiotic preparations adapted for use in the pediatric population, which constitutes as a challenge in Nursing. 


\section{RESUMO}

Objetivo: Quantificar o volume residual contido em frascos-ampola de antibióticos utilizados na pediatria. Método: Trata-se de um experimento com amostras de frascos-ampola de antibióticos utilizados em hospital pediátrico. O volume residual foi identificado calculando-se a diferença da aferição do peso antes e após a lavagem do frasco-ampola. A avaliação da diferença dos volumes residuais nos frascos-ampola foi determinada pelo teste não paramétrico de Wilcoxon para uma amostra e estabelecido o nível de significância de 5\%. Resultados: Foram selecionadas 105 amostras de antibióticos. Predominou o correto aproveitamento dos antibióticos oxacilina $(88,57 \%)$ e ceftriaxona $(94,28 \%)$, com baixos valores residuais. O mesmo não ocorreu com a benzilpenicilina procaína + potássica, pois em 74,28\% dos frascos houve descarte de volume residual superior. Conclusão: Destaca-se a necessidade de melhorias na gestão dos antibióticos na instituição em estudo, para que o volume excedente do antibiótico em frasco-ampola seja aproveitado até o tempo de estabilidade permitido, assim como é necessário que haja a adequação da forma de descarte do volume residual, que apresenta risco à saúde pública e ao meio ambiente.

\section{DESCRITORES}

Volume Residual; Antibacterianos; Infusões Parenterais; Enfermagem Pediátrica.

\section{RESUMEN}

Objetivo: Cuantificar el volumen residual contenido en frascos-ampolla de antibióticos utilizados en pediatría. Método: Se trata de un experimento con muestras de frascos-ampolla de antibióticos utilizados en hospital pediátrico. El volumen residual fue identificado calculándose la diferencia de la verificación del peso antes y después del lavado del frasco-ampolla. La evaluación de la diferencia de los volúmenes residuales en los frascos-ampolla fue determinada por la prueba no paramétrica de Wilcoxon para una muestra y establecido el nivel de significación de1 5\%. Resultados: Fueron seleccionadas 105 muestras de antibióticos. Predominó el correcto aprovechamiento de los antibióticos oxacilina (88,57\%) y ceftriaxona (94,28\%), con bajos valores residuales. Lo mismo no ocurrió con la bencilpenicilina procaína + potásica, pues en el 74,28\% de los frascos hubo descarte de volumen residual superior. Conclusión: Se destaca la necesidad de mejorías en la gestión de los antibióticos en la institución en estudio, a fin de que el volumen excedente del antibiótico en frascoampolla se aproveche hasta el tiempo de estabilidad permitido, así como es necesario que haya la adecuación de la manera de descarte del volumen residual, que presenta riesgo a la salud pública y al medio ambiente.

\section{DESCRIPTORES}

Volumen Residual; Antibacterianos; Infusiones Parenterales; Enfermería Pediátrica.

\section{REFERENCES}

1. Feudtner C, Dai D, Hexem KR, Luan X, Metjian TA. Prevalence of polypharmacy exposure among hospitalized children in the United States. Arch Pediatr Adolesc Med. 2012;166(1):9-16. DOI: 10.1001/archpediatrics.2011.161

2. Souza MCP, Goulart MA, Rosado VR, Adriano MM. Utilization of parenteral drugs in vials at a pediatric unit of a university hospital. Rev Esc Enferm USP [Internet]. 2008 [cited 2016 Oct 18];42(4):712-8. Available from: http://www.scielo.br/pdf/reeusp/v42n4/en_v42n4a13.pdf

3. Carvalho CG, Ribeiro MR, Bonilha MM, Fernandes Júnior M, Procianoy RS, Silveira RC. Uso de medicamentos off-label e não licenciados em unidade de tratamento intensivo neonatal e sua associação com escores de gravidade. J Pediatr (Rio J.) [Internet]. 2012 [citado 2016 out. 18];88(6):465-70. Disponível em: http://www.scielo.br/pdf/jped/v88n6/v88n06a04.pdf. DOI: 10.1590/S0021-75572012000600004.

4. Brasil. Ministério da Saúde; Agência Nacional de Vigilância Sanitária, Comissão da Farmacopeia Brasileira. Farmacopeia brasileira [Internet]. Brasília: ANVISA; 2010 [citado 2016 out. 18]. Disponível em: http://www.anvisa.gov.br/hotsite/cd_farmacopeia/pdf/volume1\%20 20110216.pdf

5. Hyeda A, Costa ESM. A preliminary analysis of the reduction of chemotherapy waste in the treatment of cancer with centralization of drug preparation. Rev Assoc Med Bras [Internet]. 2015 [cited 2017 Feb 23];61(4):368-74. Available from: http://www.scielo.br/pdf/ramb/ v61n4/0104-4230-ramb-61-04-0368.pdf. DOI: 10.1590/1806-9282.61.04.368.

6. Brasil. Ministério da Saúde; Agência Nacional de Vigilância Sanitária. Resolução da Diretoria Colegiada - RDC n. 33, de 25 de fevereiro de 2003. Dispõe sobre o Regulamento Técnico para o gerenciamento de resíduos de serviços de saúde [Internet]. Brasília: ANVISA; 2003 [citado 2015 fev. 23]. Disponível em: http://bvsms.saude.gov.br/bvs/saudelegis/anvisa/2004/res0306_07_12_2004.html

7. Silva ALC, Hertel VL. Perfil epidemiológico de crianças hospitalizadas em uso de antibióticos. Rev Eletr Enferm Vale do Paraíba [Internet]. 2014 [citado 2016 out. 18]; 1(6):10-3. Disponível em: http://www.publicacoes.fatea.br/index.php/reenvap/article/viewFile/1272/977

8. Strbova P, Mackova S, Miksova Z, Urbanek K. Medication errors in intravenous drug preparation and administration: a brief review. J Nurs Care. 2015;4:285. DOI: 10.4172/2167-1168.1000285.

9. Valentin A, Capuzzo M, Guidet B, Moreno R, Metnitz B, Bauer P, et al. Errors in administration of parenteral drugs in intensive care units: multinational prospective study. BMJ. 2009;338:b814. DOI: 10.1136/bmj.b814.

10. Silva LD, Passos RS, Carvalho MF. Características e evidências da produção científica de enfermeiros sobre erros de medicação no ambiente hospitalar. Rev Rene. 2012; 13(2):480-91.

11. Edwards R, Drumright L, Kiernan M, Holmes A. Covering more territory to fight resistance: considering nurses' role in antimicrobial stewardship. J Infect Prev. 2011;12(1):6-10. DOI: 10.1177/1757177410389627.

12. Alencar TOS, Machado CSR, Costa SCC, Alencar BR. Descarte de medicamentos: uma análise da prática no Programa Saúde da Família. Ciênc Saúde Coletiva [Internet]. 2014 [citado 2016 ago. 11];19(7):2157-266. Disponível em: http://www.scielo.br/pdf/csc/v19n7/14138123-csc-19-07-02157.pdf. DOI: 10.1590/1413-81232014197.09142013.

13. Cella M, Knibbe C, Danhof M, Della Pasqua O. What is the right dose for children? Br J Clin Pharmacol. 2010;70(4):597-603. DOI: 10.1111/j.1365-2125.2009.03591.x. 
14. Ivanovska V, Rademaker CMA, Dijk LV, Mantel-Teeuwisse AK. Pediatric drug formulations: a review of challenges and progress. Pediatrics. 2014;134(2):361-72. DOI: 10.1542/peds.2013-3225.

15. Wentzel J, Van Velzen L, Van Limburg M, Jong N, Karreman J, Hendrix R, et al. Participatory eHealth development to support nurses in antimicrobial stewardship. BMC Med Inform Decis Mak. 2014;14:45. DOI: 10.1186/1472-6947-14-45.

16. Sanchez GV, Roberts RM, Albert AP, Johnson DD, Hicks LA. Effects of knowledge, attitudes, and practices of primary care providers on antibiotic selection, United States. Emerg Infec Dis. 2014;20(12):2041-7. DOI: 10.3201/eid2012.140331.

17. Brasil. Conselho Nacional do Meio Ambiente (CONAMA). Resolução CONAMA n. 358 de 29 de abril de 2005. Dispõe sobre o tratamento e a disposição final dos resíduos dos serviços de saúde e dá outras providências [Internet]. Brasília; 2005 [citado 2016 out. 18]. Disponível em: http://www.mma.gov.br/prt/conama/legiabre.cfm?codlegi=462

18. Brasil. Ministério da Saúde; Agência Nacional de Vigilância Sanitária. Resolução da Diretoria Colegiada - RDC n 306, de 7 de dezembro de 2004. Dispõe sobre o Regulamento Técnico para o gerenciamento de resíduos de serviços de saúde [Interne]. Brasília: ANVISA; 2004 [citado 2016 out. 18]. Disponível em: http://bvsms.saude.gov.br/bvs/saudelegis/anvisa/2004/res0306_07_12_2004.html 